\title{
CORRECTION
}

\section{Correction to: Late-onset familial mediterranean fever: single-center experience and literature review}

\author{
Okan Aydin ${ }^{1} \cdot$ Bugra Han Egeli ${ }^{1} \cdot$ Huri Ozdogan $^{2} \cdot$ Serdal Ugurlu $^{2}$
}

Published online: 4 March 2022

(c) The Author(s), under exclusive licence to Società Italiana di Medicina Interna (SIMI) 2022

\section{Correction to: Internal and Emergency Medicine https://doi.org/10.1007/s11739-021-02912-8}

In the original version of the article, in Table 1 there is an extra unnecessary words in the parenthesis in a foreign language which should be removed.

The original article has been corrected.

Publisher's Note Springer Nature remains neutral with regard to jurisdictional claims in published maps and institutional affiliations.

The original article can be found online at https://doi.org/10.1007/ s11739-021-02912-8.

Serdal Ugurlu

serdalugurlu@gmail.com

1 Cerrahpasa Medical Faculty, University of Istanbul-

Cerrahpasa, Istanbul, Turkey

2 Division of Rheumatology, Department of Internal Medicine, Cerrahpasa Medical Faculty, University of Istanbul-Cerrahpasa, Istanbul, Turkey 